This item was submitted to Loughborough's Research Repository by the author.

Items in Figshare are protected by copyright, with all rights reserved, unless otherwise indicated.

\title{
Examining resistance, accommodation and the pursuit of aspiration in the Indian IT-BPO space: reflections on two case studies
}

PLEASE CITE THE PUBLISHED VERSION

\section{PUBLISHER}

Blackwell Publishing Ltd / @ The authors

VERSION

AM (Accepted Manuscript)

\section{LICENCE}

CC BY-NC-ND 4.0

\section{REPOSITORY RECORD}

Ravishankar, M.N., Laurie Cohen, and Amal El-Sawad. 2019. "Examining Resistance, Accommodation and the Pursuit of Aspiration in the Indian IT-BPO Space: Reflections on Two Case Studies". figshare. https://hdl.handle.net/2134/6118. 
This item was submitted to Loughborough's Institutional Repository (https://dspace.lboro.ac.uk/) by the author and is made available under the following Creative Commons Licence conditions.

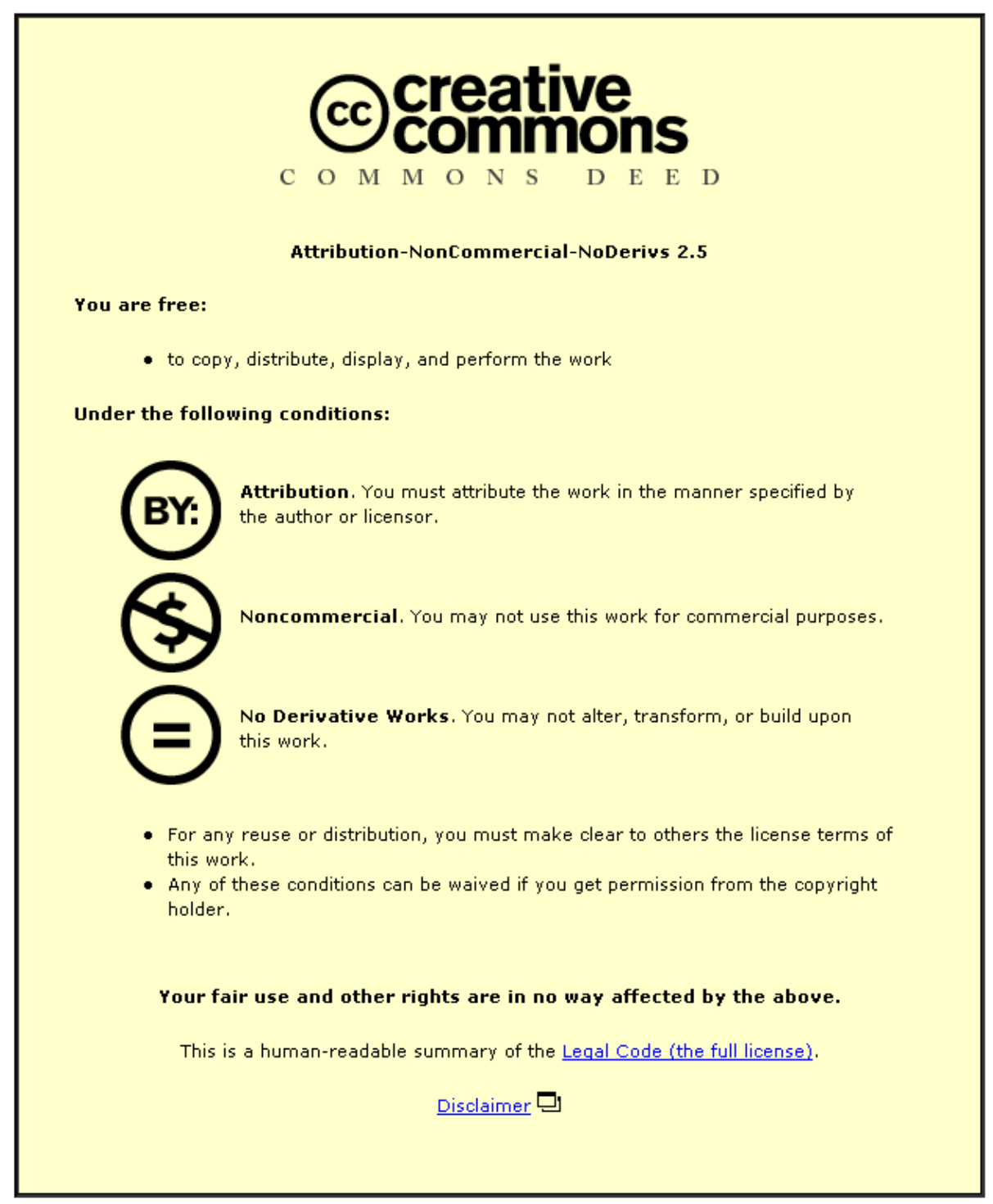

For the full text of this licence, please go to: http://creativecommons.org/licenses/by-nc-nd/2.5/ 
Examining resistance, accommodation and the pursuit of aspiration in the Indian IT-BPO space: reflections on two case studies

M.N. Ravishankar (ravi.shankar@rmit.edu.au)

\author{
School of Business IT \\ RMIT University \\ Melbourne, Victoria 3000, Australia \\ Laurie Cohen (I.cohen@lboro.ac.uk) \\ Amal El-Sawad (a.el-sawad@lboro.ac.uk) \\ The Business School \\ Loughborough University \\ Loughborough LE11 3TU, UK
}




\begin{abstract}
This paper is based on case studies of two organizations: a financial services company located in the United Kingdom and Mumbai, and an India-based information technology (IT) services company. Although they operate in different sectors and have some notable contrasts, both can be seen as typifying aspects of India's new economy. Our paper explores the lived experience of working in this economy - a perspective which has been relatively neglected in the extant literature. Drawing on Homi Bhabha's (1994) notions of ambivalence and mimicry, and V.S. Naipaul's powerful illustrations of these concepts in his fiction and non-fiction works, we report on how respondents talked about their aspirations within India's emerging economy, and examine their mobilization of particular discursive resources as forms of accommodation and resistance to the demands they face at work.
\end{abstract}

\title{
Introduction
}

The emergence and successful growth of companies in the Information Technology (IT) services and Business Process Outsourcing (BPO) ${ }^{1}$ sectors is seen as a major highlight of India's new economy (Arora \& Athreyi 2002; Dossani \& Kenney 2007). While some of these companies are indigenous, many multinational companies also operate their units in some of India's major cities and towns (Arora et al. 2001; Arora \& Gambardella 2005). For instance, in the BPO sector a number of global companies have set up subsidiaries popularly known as 'captive units' (Budhwar et al. 2006; Mehta et al. 2006). Surprisingly, despite the presence of a large body of research on offshoring, very little empirical work has looked into how employees in these rapidly growing sectors are experiencing and responding to the array of emerging organizationally mandated practices, processes and initiatives which are fast becoming integral components of their lives.

Against this background, this paper reports on case studies of two organizations: a financial services company with customer service operations located in the United Kingdom and India, and an India-based IT services firm. Although they operate in different sectors and have significant contrasts with regard to employees' educational backgrounds, skill levels and social status, both can be seen as typifying aspects of India's new economy. In embarking on this research, our aim was to deepen our understanding of situated individuals' experiences of globalization. As V.S. Naipaul, describing his tour of India which resulted in the publication of India: a million mutinies now (1990), recently explained:

...it was not always clear what I was looking for. Many people, trained in journalistic ways, thought I was looking for 'spokesmen' for various interests. I was in fact looking for something more profound and more

\footnotetext{
${ }^{1}$ While some analysts and commentators use the term BPO, others use the technically more appropriate term: IT Enabled Services (ITES)-BPO. In this paper, for purposes of brevity we use the former.
} 
intrusive: someone's lived experience (if I can so put it) that would illuminate some aspect, some new turn, in the old country's unceasing adjustment to new thought, new politics, new ideas of business (2007, March 10, p. 21).

Similarly, through these case studies we sought to learn more about how individuals employed in these dynamic sectors experienced and accounted for the work they did, in order to develop new insights into the practices and processes of offshoring. The paper addresses two central questions:

1. How do employees account for the contexts in which they work and see their future developing?

2. How do they adjust to the demands of the new forms of organization produced by the new sectors?

In the section that follows we identify key debates in the extant literature on offshoring. Focusing on cultural dimensions of offshoring, we examine how notions of employee accommodation and resistance have been conceptualized. In the next section we describe the studies on which the paper is based, detailing our research designs, approaches to data collection and analysis. Our data analysis is divided into two sections. In the first we report on how respondents talked about their aims and aspirations within India's emerging economy. In the second we discuss respondents' mobilization of particular discursive resources as forms of accommodation and resistance to the demands they face at work.

\section{Cultural dimensions of offshoring: resistance, ambivalence and mimicry in globalised companies}

The cultural dimensions of offshoring, most specifically their implications for individuals' sense of cultural identity, have generated considerable debate amongst Indian academics in particular. For example, Ramesh (2004) describes the new economy as precarious, linking it to what he sees as the increasing instability of workers' sense of who they are. The agents in his study appear to lead a double life - an "authentic", Indian, daytime life, and a phony, Western, night-time one. Of course, here Ramesh is talking about the BPO sector, rather than the IT sector, but we would suggest that the notion of 'cultural transformations' is equally relevant in the case of the more highly skilled IT employees.

Whilst dramatic and compelling, this argument strikes of an essentialism which in our view might serve to gloss over more complex processes of identity construction, connoting an image of Indian culture which is coherent and stable, and fundamentally distinct from the West. In this way, such analyses appear to ignore aspects of Western culture which have long historical roots and are deeply embedded in, and inextricable from contemporary Indian society (Chakrabarty, 2005). Furthermore, within this vision the individual appears to have little free will as to which of these identities she or he takes on. In particular, we would take issue with the implication that these new, Western forms of organization seemed 
to have landed on a cultural landscape that had previously been untouched by Western influences. Here we support the view put forward by Mirchandani (2004, 2005) (writing about the BPO sector) and D'Mello (2005) and Nicholson and Sahay $(2001,2004)$ (in the case of IT services), whose analyses depict the diverse ways in which employees have responded to the imperatives imposed by their organizations.

Consistent with our own critique, Mirchandani $(2004,2005)$ suggests that analyses in both academic and popular literatures tend towards simplification and homogenization, such that India is not regarded as a place in which people conduct their daily lives, but a kind of symbolic opposite of the west. In the words of Edward Said:

In the system of knowledge about the Orient, the Orient is less a place than a topos, a set of references, a congeries of characteristics, that seems to have its origin in a quotation, or a fragment of a text, or a citation from someone's work on the Orient, or some bit of previous imagining, or an amalgam of all these (Said, 1991, 177).

Through her focus on employees' lived experiences, Mirchandani highlights the wide variety of scripts mobilised in this transnational setting - some of which serve to reinforce dominant perspectives and others which read against the grain and are seen to disturb existing arrangements and patterns of understanding. In some ways, Mirchandani's research contrasts with Taylor and Bain's (2005) arguments about labor processes within the call centre environment in India, which mostly portrays employees in Indian call centers as victims who are denied 'opportunities to channel grievances and improve working conditions' (p.273).

In our research, Mirchandani's (2005) more complex portrayal of Indian employees as actively engaging with the imperatives of these new organizational forms has particular resonance - and is what we are seeking to understand through our focus on lived experience. Here Prasad and Prasad's (2003) discussion of post-colonial theory is potentially useful. They suggest that in organizational research, post-colonial perspectives tend to focus on the inevitable fallibility of managers' control and the creative ways in which workers express their subjectivity, 'with a view to maintaining [their] own autonomy and self-worth' (2003, p. 101). In expressing their subjectivity, workers might appear to validate existing arrangements, but in fact cast doubt; they might appear to consent, but subtly defy.

One way in which this subtle defiance happens is through mimicry. Often associated with Bhabha (1994) and illuminated in the works of Naipaul (1967), the concept of mimicry 'the miming and imitation of the colonizers by the colonized' has been used to depict the power of the colonizer, as well as its ultimate fragility. Prasad and Prasad cite Naipaul's The Mimic Men (1967) as an example of this paradox. One reading of Ralph Singh's embracing of English 
attitudes and values, and his persistent struggle to blend in, rendering himself invisible, highlights his vulnerability. However, Singh of course does not disappear. Instead his presence serves to unsettle and disrupt. Thus mimicry produces phenomena that appear to be copies, but aren't quite. Quintessentially ambivalent, it serves to police the status quo whilst at the same time offering the potential for alternative readings, for subversion and resistance:

mimicry represents ironic compromise... Which is to say, that the discourse of mimicry is constructed around an ambivalence; in order to be effective, mimicry must continually produce its slippage, its excess, its difference... The effect of mimicry on the authority of colonial discourse is profound and disturbing (Bhabha, 1994: 122-123).

Also, while the term 'resistance' in the labour process literature has been mostly used to indicate employees' refusal to accept managerial actions, we would argue that the term might also have cultural connotations and point to more subtle form of cultural defiance. For instance, the way in which employees' collectively subvert the cultural stereotyping of an external agency could be a form of cultural resistance. In the empirical sections below we turn to the data generated in our case studies to highlight examples of ambivalence and mimicry, and explore their implications for processes of accommodation and resistance.

\section{Background to the study and research design}

This paper is based on two case studies (Hammersley \& Atkinson, 1995; Bryman, 2004): an Indian IT services firm and the Mumbai site of a multi-national BPO operation, referred to in this paper as IT Co and Finance Co respectively.

IT Co is one of the largest Indian IT services companies. One of the authors conducted intensive fieldwork at IT Co in Summer 2006 and Winter 2006. Here an important source of data was semi-structured interviews with 45 employees including project managers, project leaders and software engineers from various organizational business units. All of the interviews were conducted at the headquarters of IT Co in India. Respondents were evenly split in terms of gender and ranged from 22 to 41 years old. Most of the respondents had a first degree in engineering, a few had a Masters degree in addition and one of the respondents had a PhD degree.

In contrast to IT Co, Finance Co is a wholly-owned subsidiary of the UK parent company. At the time of the fieldwork the organization operated three customer service centres in the United Kingdom and one in Mumbai. In this 'captive' unit, Indian employees worked in the same regulatory environment as their UK counterparts, within the same overall structural context, and were managed with reference to very similar human resources policies and practices, opportunities and constraints, with minor differences reflecting aspects of the local environment. In contrast to the image frequently depicted, Indian employees 
were not expected to hide their Indian-ness by taking on pseudonyms or false addresses.

The Mumbai fieldwork was conducted by two of the authors between Spring 2005 and Spring 2006. The bulk of the data was generated through 30 semistructured interviews (Kvale, 1996) with employees at different hierarchical levels, ranging from entry level agents through to the Managing Director. ${ }^{2}$ The majority were at consultant and junior management (process and team leader) levels. Respondents were split evenly in terms of gender, and most were between 20 and 30 years old, with the exception of senior managers who were in their late 30's and 40's. All of the respondents had completed first degrees and many had Masters degrees and professional qualifications.

Interviews at IT Co and Finance Co focused on employees' experiences and perceptions of work, enablement's and constraints, the impact of factors such as gender/class/caste, faith, family etc on their progress in work and career, and future aspirations. Interviews were recorded, transcribed verbatim and template analyses (King, 2004) were managed through NVivo software. In addition to these interviews, extensive field notes were generated through non-participant and participant observation. At both sites researchers were given rooms to work, with access to employees' work spaces; they had lunch in the employee canteens, joined employees for coffee and tea in the staff rooms, and observed employee training sessions.

\section{Career aspirations in contexts of opportunity and insecurity}

A striking feature of the data emerging from both studies was respondents' strong sense of aspiration. Employees felt that within India's emerging economy were career opportunities previously unavailable and saw themselves as wellplaced to take advantage of these prospects. However, the nature of these aspirations was very different between the two datasets. At IT Co respondents talked about the career futures in terms of excitement, challenge and remuneration:

In the future, I would love to find good, interesting work and to be paid highly for doing it. If everything is routine and boring, you tend to start questioning yourself about your worth as a person. Also, the remuneration package has to match and perhaps better industry standards.

Embedded within these data was a sense of entitlement. While respondents did not state that they were aiming for particular organizational positions, it seemed that given their career capital - their elite educational backgrounds, intelligence and political savvy, they aspired to (and felt they deserved) glittery careers. At Finance $\mathrm{Co}$, in contrast, respondents described their aspirations in organizational terms:

\footnotetext{
${ }^{2}$ This research was supported by the British Academy and the Economic and Social Research Council
} 
You aspire to be like [the managing director], I mean in his designation.

I would like to be the CEO- that's my dream... If you're adding value to the company, directly you're adding value to yourself. You get recognized.

Here aspirations were linked to the steady, hierarchical advancement that might be possible within this bureaucratic organization, based on time served, hard work and a positive attitude.

In both studies, our first impression of the data was a pervading sense of optimism, that India's new emerging economy offers exciting opportunities and the prospect of rewarding futures in both BPO and the IT sectors. In the words of a software engineer at IT Co:

As our CEO always says, the only way out is to move up the value chain and do things that are really high end. I believe we are slowly but surely working towards it. Once this happens the balance will definitely shift towards Indian companies. We will then be indispensable to our clients.

However, at the same time we were struck by how, alongside this sense of promise and opportunity was an embedded feeling of insecurity. Indeed, the development of a career was seen by many respondents as underpinned by a deeper quest for security. According to an agent at Finance Co:

Here [in the BPO sector] you have to at least have an undergraduate degree to get a basic job. I need to have an MBA to get a job like this, whereas in the UK it would fetch me a management position. And the material abundance that you have over there in the UK, you have everything, availability of loans, social security systems etc. Whereas I have to manage that sense of security all on my own. My family is dependent on me...

This was echoed by another agent:

You tend to think in terms of security. I was looking at getting married about a year after [starting here], so I wanted some stability, some security.

In the words of senior software engineer at IT Co:

There is a perception, even amongst some of us here that we are only doing routine jobs like software maintenance. I agree. I feel that in a strict sense we are not exactly indispensable to the clients... The belief that jobs are going out to India may create such a strong negative image within US and Europe that we may be affected. So although when I joined the 
company I was so excited that I never thought of such things, now, three years down the line, I feel a need to feel more secure. It is always there at the back of my mind.

In contrast to Ramesh's (2004) and McMillan's (2006) emphasis on insecurity as a cultural problem, in our data it emerged instead as a material one, with tangible consequences for the respondents and their families. Notwithstanding India's unprecedented growth, most respondents in both companies spoke about a sense of precariousness that pervaded the Indian context. In their opinion, the incredible competition and volatility in the two sectors, coupled with very little support by way of legal frameworks and social security systems, contributed to an urgent concern to create security for oneself and one's family. Although in purely financial terms they were much better off than their parents' generation, respondents explained that they were still some distance away from the quality of life people enjoyed in Europe and North America.

That said, the nature of the insecurity described by employees in the two organizations was different. At Finance Co respondents described the whole 'BPO space' as unstable in the sense that arrangements were only ever temporary, and there was always a possibility that client organizations might move on to other low-wage economies at any point. However, while many at IT Co saw employment prospects at more routine levels as relatively safe, they agreed that with increasing challenge and interest came greater precariousness. As a software engineer put it:

If you look at the dynamics of the IT services sector, finding jobs is not going to be a big issue at least in the near future, especially if you have an undergraduate engineering degree with decent grades. So, yes I need a job, but I am not too worried about it. But what worries me more is that over the last couple of years, all I have been doing is coding and it's as routine as it gets. Its quite frustrating at times, because I feel I am capable of doing more creative stuff. But the clients are not still comfortable giving us important work.

To understand this emphasis on interesting and challenging work at IT Co, we must speculate a bit. Relatively speaking, the IT services sector is considered to be more prestigious and attractive than the BPO sector and typically, a company like IT Co attracts the top ranking students from the top engineering colleges of the country. Perhaps, in their emphasis on interesting and challenging work, respondents at IT Co were suggesting that though job security was a concern, given their (perceived) higher technical abilities they deserved more intellectually demanding jobs. In comparison, though they were ambitious, their employment in the more volatile and politically sensitive BPO sector perhaps made respondents at Finance Co put greater emphasis on the security issue and greater trust in this established corporate 'brand' as means through which such security could be achieved. 


\section{What it takes to succeed at IT Co: hard work, enthusiasm and looking like the client}

When asked about career success strategies, respondents at IT Co did not talk about superior skills, expertise or even their social networks, but rather about the importance of language. Most particularly, they insisted that to be successful, an employee needed to demonstrate excitement and interest in organizational processes and practices by using key 'buzzwords' and jargon. Indeed, many felt under considerable pressure to enthusiastically adopt whatever happened to be the current jargon (and significantly, to demonstrate this enthusiasm). Amongst the respondents there was a consensus that currently the most popular buzzword was 'innovation'. As they explained, the top-management team had decided that the company needed to focus on innovating at work and was constantly communicating this message to all the employees. A number of respondents confessed that they were using this word often to score 'brownie points' at work. According to a project manager who had been at IT Co. for six years:

'We are all supposed to 'innovate'. This word has been over used. I use it too, better safe than sorry. I am totally cynical about it. But when everybody from top to bottom is talking about the need to innovate, we have to go along.

On one hand this display appeared to be directed internally - towards colleagues and managers as indicated in the above quote. At the same time, though, these 'performances' had a crucial, external audience. As another project manager observed:

Of course, it is not to say that innovation is not important. But I feel that as a company, we use the word for a specific reason, which is to show our clients that we use precisely the same language as they do."

Interestingly, it seemed that innovation was not always the key organizational imperative at IT Co. Several respondents explained how it had taken over from the previous buzzword, 'knowledge management' (KM), when the big idea was to manage organizational knowledge strategically through a central IT portal. Indeed, the story went that IT Co was able to 'bag' a couple of projects because clients were extremely impressed that the company was doing KM. However, respondents now saw KM as having died down, replaced instead by 'innovation'. Be it KM or innovation the strategy, it seemed, was clear: use language identical to that of the clients, and to use it often. Respondents explained that within IT Co there was a feeling that in the past the company style had been too modest and self-effacing (in other words, too Indian) and that the decision makers in the company had identified the need to be more aggressive (ie to sound more American): 
Even if we tend to exaggerate the 'let's innovate' bit, it is with the sole intention of imitating what our clients and potential clients do, to make them believe that we mean business. Internally, we are training our younger lot to use language that makes them attractive and presentable to the client. No doubt they (the young software engineers) are good workwise, but they also need to show that they are very similar to the clients.

Towards this end, respondents argued that it did not matter if they felt they were over-using particular words and phrases, even to the point of ridiculousness or exaggeration. Rather, the view was that by constantly, almost ritualistically imitating their clients' speech patterns, employees would indirectly and tactically resist their potential clients' very negative preconceptions of Indian organizations: far from being 'just another Indian sweatshop', IT Co would look like any US company. In this way, its Indian-ness would become invisible. What these data suggest, then, is that at IT Co employees used jargon to represent sameness with related notions of quality and the prospect of rapport, comfort and trust. Through adopting the language of their clients (effectively mimicking them, to use the words of Naipaul and Bhabha), IT Co employees were symbolically closing the gap between India and the US, thereby creating the possibility of developing long-term working relationships. Without such closure, employees were convinced that in the eyes of their US clients, IT Co would remain a low-wage, low quality provider of only the most routinised IT services.

In employees' deployment of the innovation discourse, accommodation and resistance appear to be inextricably linked. Underpinning the exaggerated display of accommodation in mimicking the client and appearing like the client, is a subtle sense of subversive resistance. According to a project team leader:

In a way, I am (we are) telling the client 'so far you have claimed superiority based on the presence of processes, systems etc. I know the inherent flaws in your systems. But I am going to be so well equipped in the same that you will not get anything to beat me with. If you talk about innovation, I am talking about it in a much bigger way. If you talk about $K M$, so will I. Of course, this is not too say that all these are not useful. But I am aware of the need to talk your own language to get the better of you, even as I am doing business with you.

In our previous discussion of ambivalence we highlighted Bhabha's (1994) idea that in such settings, the continued hegemony of a particular, dominant group depends on the continual repetition of particular narratives. Here we see the innovation discourse as a case in point. Through its constant repetition, from the perspective of their US clients IT Co employees become 'less foreign', and in so doing, dispel uncomfortable feelings of difference. In mimicking their clients, employees at IT Co appear to validate their clients' position, but subtly resist it, thereby promoting their own interests. Thus a certain, though precarious and fragile sense of order is established. 
As noted earlier, it is significant that while some respondents saw this mimicry as a mechanism to cope imperatives arising from relationships with clients, others consciously used jargon for internal, career reasons, in their words, to help them 'grow' within the company. Internally, employees who are able to flexibly adjust to such demands, who are attractive and unthreatening to clients, are seen as deserving recognition and reward. That is, one's ability to 'play' with these imperatives was seen as an important element of the cultural capital necessary to achieve the high status career that many at IT Co aspired to. According to a recently promoted project manager:

When it was time for my annual appraisal and I was hoping for a promotion, my immediate boss asked me to write in my progress form about my 'innovative' abilities, I did not have any such abilities, but I liberally used the word innovation in that form. And I did get promoted. My boss later told me that me being an 'innovator' had helped me get the promotion over other equally experienced colleagues. I think the lesson here for me is to be extremely aware of the jargon and use it as much as I can. Please don't think I am only about jargon. I believe I am good at what I do. But there is so much competition that I am forced to use such tactics!

In our data it became apparent that this was a game only some organizational members could play. Indeed, as one manager explained, often the younger or more naïve employees from semi-urban backgrounds found this exaggerated use of jargon funny and even irritating. Refusing to engage in this play, or lacking an understanding of its rules, such employees found progress much more difficult.

Although our focus here is on discourse, this is not to suggest that on a material level IT Co employees do not understand the importance of innovating. Rather, our point is that within It Co's highly competitive market, this is taken as given. In differentiating oneself from the competitors, what seems to be most important is the 'performance' of innovation, which involves its constant repetition both within the organization and outside. In the words of a senior project manager:

It is true that the American firms are now talking about offshoring innovation. So we are in a way exaggerating our preparedness to innovate by constantly asking everyone in the organization to show innovation in their work. It is true that a lot of us have no clue how to go about it. In fact, I don't think we will necessarily innovate by talking about it. This may sound like a contradiction, but most of us here can handle 'outsourced innovation' because we are naturally innovative. But since they do not believe us, we sort of try really hard to explicitly demonstrate our focus on innovation. 
We have thus far described the deployment of a discourse of innovation as a way of challenging US conceptions of the Indian workforce. What's interesting in this quote is the speaker's reflexive awareness of this highly politicized practice and its implicit rules of engagement. It seems that at IT Co the strategy is to accommodate the US client demands on a discursive level only, while continuing to work in the ways they see fit. Far from internalizing these discourses many employees are consciously playing with them, as if in a stage performance, in order to satisfy organizational imperatives, and ultimately in order to get on career-wise.

\section{What it takes to succeed: emphasis on hard work, enthusiasm and the discourse of 'learning and growth' at Finance Co}

As with the respondents at IT Co, respondents at Finance Co talked about the importance of working hard and being enthusiastic in order to succeed in the rapidly evolving and changing BPO space. While 'innovation' was a key word in the organizational life of employees at IT Co, employees at Finance Co underscored the need for 'learning' and 'growth'

As an agent put it:

Everybody's thinking about growth here. Every minute you're thinking about growth.

In the words of another agent,

Learning doesn't stop at any point of time and it gives stability to a person because after a certain point of time you would like to not leave, jump, hop and skip anymore in your career. So I wanted to find stability and look for a company that would be able to give me a growth opportunity. Growth, in literal terms, I would say refers to a rise in position or a rise in salary.

From the data, it appears that learning and growth has become a dominant discourse within the organization in an almost official way - perhaps, we might suggest, as an assurance seeking mechanism in the light of question marks raised about the growth opportunities in the BPO sector. It is enshrined in performance management systems, training programs, reward systems and practices. In orienting to this in their accounts, employees are demonstrating their consent to these imperatives and the values embedded within them. And as at IT Co, it's sometimes also used in a political way by employees to demonstrate their superior performance. Whilst playing political games to beat their colleagues is not seen as legitimate within this 'transparent' organization, demonstrating greater commitment to personal development, learning and growth is deemed acceptable. As an agent shared his plans:

I have well-defined goals. In the first quarter of 2005 I decided I had to be a process leader and I am one now. In 2006, when I complete my [training 
programme] I'll be looking out for a manager's position. God forbid if I don't get there then probably I might think about switching my job. [To me career success] means personal development, not exactly a jump in designation, but more additional responsibilities, personal growth, knowing more and more about products, processes. Basically personal development is more important than a designation. I will probably look for a bigger, higher designation every 2 years. I look to be a director sometime in the next 5 years.

Further, there are instances of respondents mobilizing the learning and growth discourse to somehow come to terms with experiences of unfairness. In particular, some respondents felt a need to accommodate the UK's desire to feel in charge (and their sense that this was a matter of entitlement). Such deference certainly appeared to illustrate the power of the UK voice and the relative powerlessness of the Mumbai operation. As an agent explained:

We disagree with UK at times and we put forward our disagreements in front of them, but most of the time they don't listen. For example, there's a thing called 'breaches' that happen on a complaint process, which is called a FSA breach or, a regulatory breach. We put across arguments which proves or shows that the breach should not be attributed to the Mumbai team, but to some other department. But the people in the UK would give you such an explanation which you can not debate upon further. You know, you tell them you're not accepting their explanation, but then the breach still remains on us... It's something for our managers and directors to look at...I have also told my team leader and even my operations manager to fight these kinds of things. Why do we have to take it on ourselves? It beats me hollow as to why we have to take it on, when we have everything going for us. You know, why do we have to take it? Even the team managers, if we talk to the team managers here, they say 'why don't we derive a learning out of here, and why don't we sharpen our processes'.

On one hand, this quote depicts how team managers use the learning and growth discourse to demonstrate their accommodation of and consent to existing hegemonic arrangements between India and the UK (and in so doing, to reinforce such patterns). At the same time, though, the speaker demonstrates his critical awareness of such processes and his unwillingness to accept them.

Notably, there is also a number of instances in the data of employees drawing on the learning and growth discourse, not in deference or as a means of accommodating the UK's need to be in charge, but rather to demonstrate Mumbai's superior work ethic and intellectual abilities. In the words of an agent,

When it comes to service [UK has] a lot to learn. I mean I've heard that if (you can tell me if it's correct or not) they're working from 9:30 to 5:30, at 
5:25 they are out of the systems. Here if there is this person who is supposed to log off at 5:30 UK time and the person happened to get a call at 5:25 which is a transfer from another dept, the person will take the call even if it goes on for 45 minutes. The person is ready to wait. But in the UK we've tried transferring a call, it's like, l'm just almost off, only five minutes to go. So I would say it's the attitude. You know, the willingness is what's lacking.

This view of Mumbai employees as more intelligent and more competent than their UK counterparts was expressed by people at all levels within the organization. As a senior manager put it:

I don't want to demean the quality that exists in the UK. Of course, there is a benefit to be had in terms of cost savings here. But also the quality that is delivered is different here because the basic qualification of agents is different here. We hire at least graduates here whereas in the UK that's not the case. So there is a difference in intellect and that shows in the quality of the work we do.

This of course was not a view which this respondent felt able to divulge to his UK colleagues. Indeed as we noted above, throughout this dataset were examples of Mumbai employees talking about the need to 'cover' for UK errors. However, what was possible in this context was to beat the UK at its own game. That is, Indian agents could demonstrate more and better 'learning', and their greater propensity to 'grow'. As a manager explained:

We started to grow, overcome the credibility gap. That initial phase was about building relationships, bridging the credibility gap, getting up to the target... And the next year was about consolidating the learning. So one of the things we did well was we benchmarked our performance on exactly the same basis as the UK, so we started to ensure that as the learning went up we started to meet those targets... So the second year was all about consolidating to ensure that we went up in the learning curve and delivered on par or better than the UK centres. And the third year was all about transforming. We are not in the driving seat, but I think to a large extent that we've arrived and we're recognised in the UK as an organization that can deliver..

Most notable in these data is an ambivalence in the deployment of the learning and growth discourse. On one hand there is a very strong sense that respondents believed in and embraced the discourse, using it frequently and indeed, sometimes in an almost exaggerated way. They demonstrate their acceptance of and adherence to the regimes (operational, training etc) imposed by their organization, in order to be in a position to reap what were seen as its substantial rewards. At the same time, there seems to be an awareness of the UK's more powerful position in this relationship, and the sense that to those 
involved, this position is somehow a matter of right. Therefore, any subversion of this UK hegemony must be in terms that are recognized by the UK sites as legitimate. We would argue that, much like innovation in the case of It Co, the 'learning and growth' discourse makes commonsense. Given this apparent rationality, it can therefore be seen as an ideal discursive platform on which to cast a challenge to existing arrangements.

\section{Discussion}

From our analysis above it is clear that even though there were some differences in the aspirations of the employees at IT Co and Finance Co, the discursive strategies they adopted to succeed in their respective organizations were internally consistent with what they hoped to achieve through their careers. At IT Co, even as employees talked about doing interesting and challenging work, the feeling also persisted that such opportunities were limited because (as a respondent put it) 'the clients are not giving us important work'. In response, by demonstrating their ability to innovate, it was felt that the interesting and challenging work they deserved would follow. Put differently, the deployment of this discourse of innovation was consistent not only with the strategic aims of the organization, but was also used by employees in ways that were well aligned with their career aspirations, reminiscent of Mirchandani's $(2004,2005)$ analysis of the exercise of personal agency in the call centre setting. At Finance Co where employees' focus was on upward movement in what was perceived as a highly bureaucratic set up, the learning and growth discourse was mobilized not only to defend the exaggerated deferential stance that the Mumbai office sought to adopt towards the UK, but was also used by employees in their attempts to secure internal promotions and also to outshine their UK counterparts. Here again, we would argue that the mobilization of this discursive resource as a vehicle for maneuvering between these potentially contradictory imperatives demonstrates a powerful sense of individual agency.

Both Bhabha (1994) and Naipaul $(1958,1967,1990)$ depict ambivalent postcolonial worlds in which the interplay between accommodation and resistance is a persistent and dynamic feature. Likewise, this ambivalence permeates the accounts we heard of life at IT Co and Finance Co. Through our examination of the discourse of innovation at IT Co, and of learning and growth at Finance Co, we have demonstrated how employees use these discursive resources to negotiate between the imperatives and expectations of their working environments and their own desire for career success (which we would argue is inextricably linked to their quest for security). Informed by Bhabha's (1994) concept of the 'demand for narrative' we have argued that the constant repetition, even exaggeration of these discourses in both organizations serve to create a sense of order and orderliness, whilst at the same time elucidating its fundamental precariousness and fragility.

Running through our data is a strong sense of performativity - that the deployment of these discursive techniques is conscious, strategic and geared to 
a particular 'audience'. In the case of IT Co, this audience is first and foremost the US clients. With strong echoes of Ralph Singh in Naipaul's (1967) The Mimic Men, we have argued that through deployment of the discourse of innovation, IT Co employees sought to look as much like the client as they could. However, mimicry is of course not just deference, flattery or the acting out of a particular hegemonic ordering. Rather it can be deeply ironic, working in subtle ways to challenge or subvert. In the IT Co respondents' discussions of innovation, there were examples of all of these. First, these IT professionals did see their work as involving innovation and so in this context some innovation talk was appropriate and reasonable. Second, in much of the IT Co data there was also a sense of respect for the position of the US clients, and indeed some employees saw career success in terms of developing ever closer working relationships with these clients. In this context, adopting the clients' language could be seen as a form of flattery, a way for IT Co employees to ingratiate themselves with these people. In these cases the use of this discourse could be seen in terms of accommodation - serving to uphold and reinforce existing arrangements. At the same time, though, we would argue that through such mimicry, IT Co employees sought to close the gap between India and the US, and in doing so, to effectively subverting long-standing connotations of foreign-ness and sweatshop labour and replacing them with notions of quality, progress and above all familiarity. Notable here is way in which this acceptable discursive device is being used in ways that unsettle existing, commonsense understandings of the social order. And finally we discussed a much more defiant use of the innovation discourse, where employees quite deliberately changed the way they spoke in line with client expectations, but with absolutely no intention of altering any of their working practices in light of these demands.

At Finance Co there was likewise a strong feeling of performativity in the deployment of the learning and growth discourse, but rather than being geared to an external client, in this case the audience was the UK Finance and Co operation - in particular the three UK customer service centres which the Mumbai centre worked alongside. Here again, our data analysis revealed the complex and sometimes contradictory functions of this discursive maneuvering. Through their continued emphasis on learning and growth the Mumbai employees demonstrated, first, their fitness to be part of this organization - they could keep up with the UK. At the same time, it served to express their deference and subordination to the UK, a position they were effectively allocated and which within the organization as a whole was assumed to be 'natural'. Alongside the use of learning and growth to accommodate and arguably to reinforce existing arrangements were those examples in which the discourse was used, almost mockingly, to demonstrate Indian employees' greater competence and intelligence (and by comparison, the UK's inadequacies in this respect). Here as at IT Co, we would argue that the ambivalence of the context meant that all three approaches were possible, even at the same time. 
In addition to these powerful (though at the same time seemingly vulnerable) 'audiences' - the client, on the part of IT Co, and the UK partner sites in the case of Finance $\mathrm{Co}$, in both organizations respondents talked about how they consciously drew on these discourses to present themselves as promotable to their managers. In this sense, innovation and learning and growth were used as career strategies, targeted at those who were charged with making decisions about employees' advancement. Significantly, respondents from both organizations spoke of those who understood this politicized process, played by its rules and achieved in its terms, and the casualties of the system who either didn't understand or refused to participate in the process.

\section{Concluding remarks}

In light of our findings, we would take issue with critics who argue that outsourcing and offshoring arrangements are imposing a set of conditions on the Indian workforce which they appear to have no choice but to accept and which are serving to fracture and destabilise workers' sense of who and what they are. On the contrary, what is most striking in our data is the sense of respondents putting on a discursive performance which from our data does not appear to be affecting their sense of identity in any obvious way. In fact, we would suggest that such a performance is seen as a minimum requirement to ultimately overcome the west. Rather than taking confrontational positions in the debate about the hegemonic nature of the arrangements in these sectors, employees appear ready to openly embrace what are seen as western processes and practices. Yet this is seen only as a mechanism or as part of a performance necessary to gain legitimacy as a globally relevant entity, which can than compete on an equal footing with the leading western companies.

\section{References}

Arora, A., Arunachalam, A., Asundi, J. and Fernandes, R. 'The Indian software services industry', Research Policy (30:8), 2001, pp. 1267-1287.

Arora, A. and Athreye, S. 'The software industry and India's economic development', Information Economics and Policy (14:2), 2002, pp. 252-273.

Arora, A. and Gambardella, A. 'The globalization of the software industry: perspectives and opportunities for developed and developing countries', NBER innovation policy and the economy (5:1), 2005, pp. 1-32.

Bhabha, H. The location of culture. London and New York: Routledge, 1994.

Bryman, A. Social research methods. Oxford: Oxford University Press, 2004.

Budhwar, P.S., Luthar, H.K. and Bhatnagar, J. 'The dynamics of hrm systems in Indian bpo firms', Journal of Labor Research (27:3), 2006, pp. 339-360. 
Chakrabarty, D. Legacies of Bandung: decolonialisation and the politics of culture. Economic and Political Weekly, 2005, November 12

(http://www.epw.org.in)

D'Mello, M. "'Thinking local, acting global": issues of identity and related tensions in global software organizations in India', Electronic Journal of Information Systems in Developing Countries (22:2), 2005, pp. 1-20.

Dossani, R., and Kenney, M. 'The next wave of globalization: relocationg service provision to India', World Development (35:5), 2007, pp. 772-791.

Hammersley, M. and Atkinson, P. Ethnography: principles in practice, $2^{\text {nd }}$ edition. London: Routledge, 1995.

King, N. 'Using interviews in qualitative research', in C. Cassell and G. Symon (Eds.) Essential guide to qualitative methods in organizational research, London: Sage, 2004, 11-22.

Kvale, S. InterViews. London: Sage, 1996.

McMillan, D. 'Outsourcing identities. Call centres and cultural transformation in India', Economic and Political Weekly, 2006, January $21^{\text {st }}, 235-241$ (http://www.epw.org.in).

Mehta, A., Armenakis, A., Mehta, N., and Irani, F. "Challenges and Opportunities of Business Process Outsourcing in India," Journal of Labor Research (27:3), 2006, pp. 323-338.

Mirchandani, K. 'Practices of global capital: gaps, cracks and ironies in transnational call centres in India', Global Networks (4,4), 2004,, pp. 355-373.

Mirchandani, K. 'Webs of resistance in transnational call centres. Strategic agents, service providers and customers'. In R. Thomas, A. Mills and J. Helms Mills (Eds.) Identity politics at work: resisting gender, gendering resistance. London: Routledge, 2005, pp. 179-195.

Naipaul, V.S. The Mimic Men. London: Penguin Books, 1967.

Naipaul, V.S. 'The Long Way Round', The Guardian, 10 March, 2007, p. 21.

Naipaul, V.S. India: a million mutinies now. London; William Heinemann, 1990.

Nicholson, B., and Sahay, S. 'Some political and cultural issues in the globalization of software development: case experience from Britain and India', Information and Organization (11:1), 2001, pp. 25-43.

Nicholson, B., and Sahay, S. 'Embedded knowledge and offshore development', Information and Organization (14:4), 2004, pp. 329 -365. 
Prasad, A. and Prasad,P. 'The empire of organizations and the organization of empires: postcolonial considerations on theorizing workplace resistance. In A. Prasad (Ed.) Postcolonial theory and organizational analysis. London: Palgrave, 2003, pp. 95-120.

Ramesh, B. "'Cyber Coolies" in BPO. Insecurities and vulnerabilities of nonstandard work', Economic and Political Weekly, 2004, January 31 (http://www.epw.org.in).

Said, E. Orientalism. London: Penguin Books, 1978.

Taylor, P. and Bain, P. "India calling to the far away towns": the call centre labour process and globalization', Work, Employment and Society (19:2), 2005, pp. 261-282. 